\title{
What's Good for GM...? \\ Using Auto Industry Stock Returns to Forecast Business Cycles and Test the $Q$-Theory of Investment
}

\author{
Gregory R. Duffee \\ Federal Reserve Board \\ Mail Stop 91 \\ Washington, DC 20551 \\ 202-452-3055 \\ gduffee@frb.gov
}

\author{
Stephen Prowse \\ Federal Reserve Bank of Dallas \\ 2200 N. Pearl Street \\ Dallas, TX 75201 \\ 214-922-5230 \\ stephen.d.prowse@dal.frb.org
}

First version August 1992

Current version August 1996

\begin{abstract}
We examine the ability of auto industry stock returns to forecast quarterly changes in the growth rates of real GDP, consumption, and investment. We find that auto stock returns are superior to aggregate stock market returns in predicting growth rates of GDP and various forms of consumption. The superior predictive power of auto returns holds for both in-sample and out-of-sample forecasts and has not declined over time. We then apply a finding in this paper - that market returns have no explanatory power for future output or consumption growth when auto returns are included in the regression - to analyze the causal relation between the stock market and investment. We use auto returns to proxy for forecasts of future fundamentals, allowing market returns to capture the effect of the stock market on investment. We find that aggregate returns forecast equipment investment in the presence of auto returns, providing empirical support for $q$-theory. Results for structures investment are less convincing.
\end{abstract}

We thank Karen Dynan and Ben Friedman for helpful comments. The analysis and conclusions of this paper are those of the authors and do not indicate concurrence by the Board of Governors or the Federal Reserve Banks. 


\section{Introduction}

The stock market forecasts future growth rates of aggregate output, consumption, and investment. ${ }^{1}$ Because of the strength of this empirical relationship, academics and professional forecasters often employ changes in the level of the broad stock market, among many other variables, in their attempts to predict future economic growth. The S\&P 500, for example, is used as a leading indicator by the Department of Commerce. The MPS model of the U.S. economy developed by the Federal Reserve Board, as well as the macro-model developed by Data Resources, Incorporated, use stock market prices (in one form or another) as explanatory variables in their consumption and investment functions. ${ }^{2}$

There are three explanations for the forecasting power of the stock market. First, stocks are wealth, thus an increase in the value of the stock market raises consumption. Second, stock prices are related to Tobin's (1969) q, thus an increase in the value of the stock market raises investment. Third, stock prices are forecasts of future corporate earnings, which rise in boom periods. In the absence of this third explanation, there would be no reason to investigate whether the stock return to a given industrial sector was superior to the aggregate stock return in forecasting future economic growth. Both the wealth effect and the $q$ effect depend on the aggregate stock market, not on any particular sector.

However, the strength of the relation between corporate earnings and the business cycle is likely to vary across corporate sectors. (At an extreme, the earnings of an acyclical industry will be unrelated to macroeonomic movements.) Therefore it is plausible that stock returns to sectors that are very sensitive to business cycle movements may outperform aggregate stock returns in forecasting business cycles. Surprisingly, though, we have found no previous investigations of this issue in the academic literature.

1 The relevant literature is too large to exhaustively list here. Early work includes Bosworth (1975) and Hall (1978). Recent evidence is in Estrella and Mishkin (1996).

2 The stock market briefly fell into disfavor with its exclusion from Stock and Watson's (1989) experimental leading index, but Stock and Watson (1993) subsequently found that the level of the stock market was one of the few variables that forecasted the 1990 recession. 
We focus on the ability of auto industry stock returns to forecast changes in macroeconomic variables. We find that auto returns are substantially better forecasters of real GDP and a variety of measures of real aggregate consumption than are market returns. In particular, in regressions of consumption on stock returns, we find that the presence of auto returns reduces the explanatory power of market returns to zero. Drawing on the literature on consumption, we investigate why auto returns are such a good predictor of future changes in consumption. We find that for expenditures on nondurables and services, lagged auto returns have predictive power above that contained in lagged consumption or lagged income. We also find that the superior performance of auto returns at forecasting durable goods expenditures is unlikely to be simply a consequence of the fact that auto-specific expenditures make up a large fraction of total durables expenditures. We are left with the conclusion that that the auto industry is a bellwether of the macroeconomy, hence auto industry stock returns are largely driven by the information that investors have about future business cycle fluctuationsinformation that is not in current aggregate consumption or income.

Clearly, any investigation of the forecasting power of sectoral stock returns can generate spurious results. There are many industries, and simply by chance, some are likely to outperform the aggregate market in forecasting over a given sample period. Ultimately, this literature cannot insulate itself fully from data mining; for example, we would not have written this paper if the results were not so striking. Nonetheless, we argue that these results are very robust. In each of past four decades, auto returns were superior to market returns in one-quarter-ahead forecasts of GDP growth. In addition, we conduct some simple data-mining exercises in an effort to construct a forecasting measure superior to auto returns, and our efforts are unsuccessful.

We argue that our results cannot be used to evaluate the strength of the wealth effect of the stock market on consumption, but they can be used indirectly to evaluate the empirical importance of $q$-theory. It is well-documented that aggregate stock returns lead investment, but the interpretation of this pattern is unclear. Does the stock market have real effects on investment or does it merely passively forecast future changes in investment? A host of academic papers have tried to identify the structural relation between the stock 
market and investment. These papers have tried to separate the pure forecasting ability of market returns from the market's postulated direct effects on future investment. The decomposition is extremely difficult to achieve in practice, because no one has found variables that both encompass the forecasting ability of the stock market (i.e., there are few good instruments) and are not subject to a simultaneity bias (i.e., are truly lagged variables).

What is needed is a measure of forecast of future fundamentals that completely captures the forecasting ability of market returns. Our solution is to use auto returns. We use the fact that market returns have no incremental forecasting power for aggregate consumption growth when auto returns are included as explanatory variables. Therefore in a regression of investment on lagged market and auto returns, market returns will capture only the real effects of the stock market on investment, while auto returns proxy for changes in expected future consumption.

Our results for investment are the reverse of those for GDP and consumption. Auto returns have no explanatory power for investment (either durables equipment or nonresidential structures) when auto and market returns are included in an accelerator-type investment model. By contrast, market returns are statistically significant for investment in durable equipment, although not for investment in nonresidential structures. We interpret our results as (weakly) supportive of $q$-theory; in other words, aggregate stock returns appear to cause changes in durable equipment investment instead of simply forecasting changes in consumption, which lead to greater investment.

The next section looks at the relative ability of auto and market returns to forecast future changes in GDP and various measures of consumption. It also explains why our results are uninformative about the structural relation between the stock market and consumption. The third section examines the relation between the stock market and investment. The fourth section concludes.

\section{Forecasting Output and Consumption}

\subsection{Data Description}

Quarterly levels of output and consumption from 1959:3 through 1996:1 are from the most recent NIPA revision. They are seasonally adjusted, chain- 
weighted and measured in 1992 dollars. Earlier data is from the 1982 NIPA revision. The measure of output from this revision is GNP instead of GDP. This revision used 1982 weights instead of chain weights. The series are spliced together by equating their 1959:3 values.

The aggregate quarterly return to the market (henceforth known as the "market return") is denoted $R_{m, t}$ and is measured by the return to the Center for Research in Security Prices (CRSP) NYSE/AMEX value-weighted index. The quarterly return to the automotive industry is denoted $R_{a, t}$. It is the value-weighted return to firms with the three-digit SIC code 371 . Both the firms' stock returns and their SIC codes are taken from the CRSP tape. Returns are measured in logs, include dividends, and are three-month sums of monthly returns less the three-month Treasury bill rate that prevailed on the last day of the previous quarter. ${ }^{3}$

Not surprisingly, the stock return to the auto industry is more volatile than is stock return to the entire market. Over the period 1953:1 through 1995:4, the standard deviation of quarterly auto stock returns was 11.0 percent compared with 7.9 percent for the market return. The returns tended to move together: Their correlation was 0.74 over this period.

\subsection{Forecasting Output}

There is ample evidence that stock prices contain information about future movements in output. Fama (1981) showed that stock returns are positively related to the subsequent growth rate of real GNP. Moore's (1983) tabulation of the forecasting record for the years 1873-1975 has the stock market as the best single leading indicator of the business cycle. In this paper we focus on forecasting the quarterly growth rate of output given previous quarterly stock returns, as in (1):

$$
\Delta \log \left(G D P_{t}\right)=b_{0}+\sum_{i=1}^{4} b_{m, i} R_{m, t-i}+\sum_{i=1}^{4} b_{a, i} R_{a, t-i}+e_{t}
$$

We estimate (1), subject to various restrictions, using ordinary least squares over the period 1954:1 through 1996:1. The starting point is chosen

3 The results are altered only slightly if raw returns or ex-dividend returns are used. 
because it is roughly comparable to that used in Campbell and Mankiw (1991) and because it avoids any possible distortions caused by the Korean war.

The results are displayed in columns [1] through [3] of Table 1 . We measure the forecasting ability of a regression by its adjusted $R^{2}$. In addition, for each regression, we report two joint significance tests on each set of stock return variables. The first tests the hypothesis that all four coefficients on a given stock return equal zero. The second tests the hypothesis that the sum of the four coefficients equals zero. Because we adjust the variance-covariance matrix of the estimated coefficients for generalized heteroskedasticity and one lag of moving average residuals, the appropriate tests of joint significance are asymptotic $\chi^{2}$ tests instead of $F$ tests.

Column [1] in Table 1 reports the results of estimating (1) using only market returns. Four quarterly lags of market returns explain (in an adjusted $R^{2}$ sense) 17.8 percent of the variation in the growth rate of quarterly GDP. All of the lags of market returns are statistically different from zero, both individually and jointly. The point estimates imply that a one-standarddeviation stock return in a given quarter (7.9 percent) corresponds to a cumulative increase in output of 0.81 percent.

When only auto stock returns are used to forecast (column [2]), the adjusted $R^{2}$ is higher than that for market returns, at 22.4 percent. Again, all of the lags of the stock returns are individually and jointly significant. The point estimates imply that a one-standard-deviation stock return $(11.0$ percent) corresponds to a cumulative increase in output of 0.91 percent.

Column [3] reports the results of estimating (1) with both market and auto stock returns. The market returns are not significantly different from zero, either economically or statistically. The coefficients are individually and collectively statistically indistinguishable from zero. By contrast, the coefficients on the auto returns are little changed by including market returns in the regression, and the hypothesis that the sum of the auto return coefficients is zero can be rejected at the $1 \%$ level. Auto returns are superior to market returns at predicting output.

Fischer and Merton (1984) showed that the stock market's forecasting ability for output can be traced to the fact that stock prices lead both aggregate consumption and investment expenditures. A natural question is to 
what extent the superior abililty of auto returns to predict output carries over to predicting consumption and investment?

\subsection{Forecasting Consumption Expenditures}

We first look at aggregate consumption expenditures. Our specification is identical to (1) with GDP replaced by aggregate personal consumption expenditures (PCE). The results, which are displayed in columns [4] through

[6] of Table 1, are similar to those reported for aggregate output. Columns [4] and [5] show that auto returns have more predictive power than market returns, with an adjusted $R^{2}$ of 25.2 percent versus 18.9 percent. Column [6] shows that when both auto and market returns are included, market returns have no explanatory power. The coefficients on the market returns are indistinguishable from zero, both individually and jointly.

It is plausible that the relation between consumption and stock returns depends on the type of consumption. Autos are a durable good. Expenditures on motor vehicles and parts typically constitute 40 to 50 percent of total expenditures on durable goods. Therefore, perhaps auto stock returns are superior at forecasting consumption simply because they are better at forecasting motor vehicle expenditures. In addition, theory suggests that the stochastic process followed by expenditures on durables will differ from that for expenditures on nondurables and services. Hall (1978) argues that expenditures on nondurables and services should follow a random walk, while Mankiw (1982) notes that the same framework implies that expenditures on durables should follow an $\operatorname{ARMA}(1,1)$. Since the univariate stochastic processes may differ, the relation between the consumption processes and stock returns may also differ.

To investigate these issues, we split consumption into expenditures on durables and expenditures on nondurables and services. We first examine expenditures on durables. Columns [1] through [3] of Table 2 present the results of regressing log changes in quarterly expenditures on durables on four lags of market and auto returns. Column [1] documents that aggregate stock returns forecast durable goods consumption. The adjusted $R^{2}$ is 16.8 percent and the coefficients are jointly significant at the $1 \%$ level. These results are in stark contrast to earlier results in Mankiw (1982). He used a similar specification and was unable to reject the hypothesis that the coefficients on 
the lagged level of the S\&P 500 were all zero. ${ }^{4}$

As with output and total consumption, auto stock returns are better than aggregate returns at forecasting expenditures on durables. The adjusted $R^{2}$ using only auto returns is 20.5 percent. The point estimates imply that a one-standard-deviation stock return corresponds to a cumulative increase in durable goods expenditures of 2.77 percent. When both types of stock returns are included, market returns are statistically insignificant, while auto returns remain significant at the $1 \%$ level.

Are auto returns better at predicting durable goods expenditures because they are better at predicting expenditures on motor vehicles? Columns [4] to [6] of Table 2 help address this question. They report regressions with expenditures on motor vehicles and parts as the dependent variable. The results indicate that, not surprisingly, auto returns are superior to market returns at forecasting these expenditures. What is surprising is that for each regression, the explanatory power of stock returns (as measured by adjusted $R^{2}$ ) is lower than for the corresponding regression with total durable goods expenditures. In other words, auto stock returns are better at forecasting expenditures on all durable goods than they are at forecasting expenditures on motor vehicles and parts. It is not clear what to make of this result-it might reflect substantial measurement error in expenditures on motor vehicles. On balance, however, these regressions do not suggest that the explanatory power of auto returns for durable goods owes entirely to their relation to automotive expenditures. ${ }^{5}$

We next look at quarterly expenditures on nondurables and services, which we denote $C_{n o n d u r, t}$. Log changes in $C_{n o n d u r, t}$ are regressed on four lags of market and auto stock returns. Column [1] of Table 3 documents that $C_{\text {nondur,t }}$ rises after the aggregate stock market rises. This result is

4 We tried to replicate Mankiw's results using his exact specification and his sample period without success. This remains a puzzle.

5 Curiously, stock returns (either market or auto) have only a minimal ability to forecast expenditures on durable goods excluding motor vehicles. The adjusted $R^{2}$ for a regression of log changes in durables ex autos on four lags of market returns is 5.04 percent, compared with 6.06 percent with four lags of auto returns. When both types of stock returns are included in the regression, none of the joint hypotheses examined in this section are rejected at the $5 \%$ level. 
consistent with Hall (1978), who estimated essentially the same regression in levels instead of logs. Although this relation is very strong in a statistical sense (the hypotheses that the coefficients all equal zero is overwhelmingly rejected), it is economically weak. The adjusted $R^{2}$ is only 10.2 percent, while the point estimates imply that a one-standard-deviation increase in the stock market corresponds to a cumulative increase in $C_{n o n d u r, t}$ of only 0.3 percent.

Using adjusted $R^{2}$ as a metric, column [2] in Table 3 documents that auto industry stock returns are substantially better than market returns at forecasting the growth of $C_{n o n d u r, t}$. The adjusted $R^{2}$ is 16.3 percent, or 1.6 times the adjusted $R^{2}$ for market returns. As with the market return, the economic importance of this predictability is not large. The point estimates imply that a one-standard-deviation increase in auto stocks corresponds to a cumulative increase in $C_{n o n d u r, t}$ of 0.4 percent. Column [3] of Table 3 reports that when both returns are included, the market returns are statistically insignificant, while auto returns are significant at the $1 \%$ level.

Why are auto stock returns so much better than market returns at predicting the growth of $C_{n o n d u r, t}$ ? Consumption theory points to a number of possible explanations. The first possibility is the Working (1960) effect. Even if instantaneous nondurables consumption is a martingale, as in Hall's model of consumption, time-averaged nondurables consumption is predictable with lagged values of variables that are instantaneously correlated with nondurables consumption. ${ }^{6}$ In our data, the contemporaneous correlation between log-differenced expenditures on nondurables and services and auto industry stock returns is 0.24 , versus 0.18 for aggregate stock returns. Therefore the Working effect may be responsible for the greater ability of auto stock returns to predict changes in $C_{n o n d u r, t}$.

The second possibility is that auto stock returns are more closely correlated with variables previously shown to forecast $C_{n o n d u r, t}$ than are mar-

6 If instantaneous consumption follows a martingale, changes in timeaveraged consumption will exhibit a first-order serial correlation of 0.25 . Therefore the first lag of any variable instantaneously correlated with consumption will forecast changes in time-averaged consumption. This result holds even if lagged changes in consumption are included as forecasting variables, as long as the non-consumption variable is not time-averaged in exactly the same way. 
ket stock returns. In particular, Campbell and Mankiw (1991) find that $\Delta \log C_{n o n d u r, t}$ is forecastable with lags two through six of $\Delta \log C_{n o n d u r, t}$. (They omit the first lag because of the Working effect.) Therefore auto returns may be better than market returns at predicting future changes in $C_{\text {nondur, } t}$ simply because they are more closely correlated with contemporaneous changes in $C_{\text {nondur, } t}$.

These possibilities are empirically tested in Table 4. Log changes in $C_{n o n d u r, t}$ are regressed on lags two through six of itself and lags two through four of auto industry stock returns, as in (2):

$$
\Delta \log C_{n o n d u r, t}=b_{0}+\sum_{i=2}^{6} b_{c, i} \Delta \log C_{n o n d u r, t-i}+\sum_{i=2}^{4} b_{a, i} R_{a, t-i}+e_{t}
$$

Column [1] presents results for the regression using only auto returns as explanatory variables, column [2] for the regression using only lagged $C_{\text {nondur, }}$, and column [3] for the unrestricted regression. The adjusted $R^{2}$ in column [1] is 5.8 percent, which is substantially lower than the adjusted $R^{2}$ of 16.3 percent when the first lag of auto returns is included (from column [2] of Table 3). The difference between these adjusted $R^{2}$ 's is an upper bound on the importance of the Working effect. However, because lags two through four help explain future growth in $C_{\text {nondur, }}$, it is highly likely that the explanatory power of the first lag is not entirely a consequence of the Working effect.

A comparison of columns [2] and [3] indicate that auto returns contain information concerning future $C_{\text {nondur, } t}$ that is not in lagged values of $C_{n o n d u r, t}$. The adjusted $R^{2}$ using both sets of explanatory variables is 11.8 percent, versus 9.3 percent for lagged $C_{\text {nondur, },}$ alone. In column [3], the joint hypothesis that all of the coefficients on the auto returns are zero is rejected at the $5 \%$ level, as is the hypothesis that their sum is zero. ${ }^{7}$

7 For comparison, we also estimated these regressions with market returns in place of auto returns. Details are available on request. Briefly, the regression of $\log$ changes in $C_{n o n d u r, t}$ on four lags of market returns had an adjusted $R^{2}$ of 4.5 percent. When both lagged consumption and lagged market returns were included as explanatory variables, the hypothesis that the 
Campbell and Mankiw (1991) found that variables such as lagged expenditures on nondurables and services and aggregate income explained future changes in expenditures on nondurables and services only to the extent that they explained future changes in aggregate income. Their interpretation of this evidence is that there are two types of consumers. The first type consumes their permanent income, while the second consumes their current income. With this setup, consumption is forecastable only to the extent that income is forecastable.

If this model is correct, lagged auto returns must be better than market returns at forecasting aggregate income growth. This hypothesis is investigated in Table 5. It presents regressions of log changes in real personal disposable income on lags two through four of market and auto returns. The table indicates that market returns are better than auto returns at forecasting future income: The adjusted $R^{2}$ for market returns is 5.5 percent, versus 4.8 percent for auto returns. This evidence casts doubt on the notion that auto returns forecast $C_{n o n d u r, t}$ only because they help forecast future income. $^{8}$

\subsection{Robustness}

There are two good reasons to be skeptical of these results. The first is that the importance of the auto industry to the U.S. economy has declined over time. In the late 1950s, the market capitalization of the auto industry as a fraction of the total capitalization of NYSE/AMEX firms, was as high as 9.1 percent. This ratio fell to as low as 1.7 percent during the 1990 s. Perhaps the statistical relation between auto industry stock returns and the aggregate economy has similarly declined over time, so that the returns are no longer a useful forecasting tool. The second is that investigations of this type are at great risk of data mining. We believe our results indicate that the auto industry is a bellwether of the macroeconomy. Indeed, the auto industry has

sum of the four market return coefficients was zero could not be rejected at the $5 \%$ level. (However, the joint hypothesis that all four coefficients were zero could be rejected at the $5 \%$ level.)

8 Campbell and Mankiw used instrumental variables to regress log changes in $C_{n o n d u r, t}$ on contemporaneous changes in income. Such an approach is not appropriate here because auto returns are such a poor instrument for future income. See Nelson and Startz (1990). 
long been regarded as a major engine of economic growth. ${ }^{9}$ Nonetheless, it may be simply be by chance that the auto industry is the one sector that has good in-sample forecasting properties. After all, if 100 researchers examine 100 randomly chosen industries for their ability to forecast economic growth, one of them is likely to succeed. ${ }^{10}$

Although we cannot completely insulate ourselves from the latter criticism, the arguments in this paper will be more convincing if the predictive power of auto stock returns is strong throughout the entire 1954:1-1996:1 period examined here. We consider this issue with series of rolling regressions designed to produce one-step-ahead out of sample forecasts of log changes in GDP. ${ }^{11}$

For each quarter $t$, we estimate three restricted versions of eq. (1) with data from 1954:1 through $t$. The first version sets the coefficients on both types of stock returns to zero. In other words, we simply estimate the mean log change from 1954:1 through $t$. The second version sets the coefficients on auto stock returns to zero and the third version sets the coefficients on market stock returns to zero. Then for each version, the predicted value of the quarter $t+1 \log$ change in GDP is calculated. This procedure results in three series of one-step-ahead forecasts of log changes in GDP. ${ }^{12}$

The root mean squared errors (RMSE) of these forecasts are calculated for each decade and reported in Table 6. The important lesson to take from this table is that the superior predictive power of auto returns has not waned

9 As alluded to in the title of our paper, "What is good for the country is good for General Motors, and vice versa." The statement is by Charles E. Wilson, made in 1953 during his confirmation hearings for Defense Secretary. Mr. Wilson's view was likely influenced by his earlier position as president of GM.

10 In fact, we tested the forecasting ability of a variety of industries but found no other sector that is superior to the aggregate stock market in forecasting macroeconomic variables.

11 As another test of the stability of these results over time, we reestimated each of the regressions reported in Tables 1, 2, and 3, allowing for all of the coefficients to change after 1974:4 (the midpoint of the time series). Of the 15 regressions, only one (column [6] in Table 2) exhibited instability in the coefficients on the stock return variables at even the $10 \%$ level of significance.

12 Note that these regressions could not have been estimated at quarter $t$, because NIPA GDP data is reported with a lag. 
over time. In every decade, the forecasts generated with auto stock returns have smaller errors than do the forecasts generated with either a simple constant or with market stock returns. The ratio of the RMSE for auto returns to the RMSE for market returns ranges from 0.87 during the 1960s to 0.97 during the 1970s. The relative predictive success of auto returns during the 1960s is more a consequence of poor forecasting on the part of market returns than superior forecasting on the part of auto returns-forecasts produced with just a constant term were better than forecasts produced with market returns during the 1960s.

For additional evidence that this paper is not just an exercise in data mining, we explicitly go data mining to see if we can construct a stock return that is a better forecaster than auto industry stock returns. Our data-mining tool is a "consumption beta." Auto industry stock returns are relatively responsive to contemporaneous consumption. A regression of auto stock returns on contemporaneous log-differenced consumption (PCE) produces a coefficient of 3.15, with a heteroskedasticity-consistent standard error of 1.03. By contrast, the market as a whole has a low consumption beta, with a coefficient of only 0.76 , with a standard error of 0.79 . It is plausible that stocks with high consumption betas are better at forecasting consumption than stocks with low consumption betas. We therefore look for high-beta stocks with which to forecast.

For each of the 5972 stocks on the CRSP AMEX/NYSE monthly tape with at least 12 quarters of data from 1954:1 through 1995:4, we estimate a consumption beta. We then take the quintile of stocks with the highest consumption betas and form a value-weighted return to the stocks. The median consumption beta of the stocks used to construct the high-beta index return is 9.33 , versus a median of 1.49 for the universe of 5972 stocks. The consumption beta of the high-beta value-weighted index is 7.08. Thus the return to this index is much more responsive to contemporaneous consumption than is the auto industry stock return.

Nonetheless, this index produces poorer forecasts of consumption than does the auto industry return. We summarize the results here; details are available on request. The adjusted $R^{2}$ of a regression of log changes in consumption on four lags of the return to the high-beta index is 17.2 percent, which is substantially lower than the 25.2 percent in column [5] of Table 
1. This relatively weak explanatory power holds for both the durables and nondurables plus services components of aggregate consumption. The only variable that high-beta returns are better at forecasting than auto returns is log-differenced GDP, and the difference in forecast power is very slightan adjusted $R^{2}$ of 22.8 percent versus 22.4 percent in column [2] of Table 1. On balance, this systematic data-mining effort failed to produce a better forecasting tool than auto returns. This failure lends support to the idea that the relation between auto returns and future variations in the business cycle is not an accidental artifact of the data, but instead reflects a fundamental relation.

\subsection{Implications for the Wealth Effect}

We found above that aggregate stock market returns have no incremental ability to forecast future consumption growth when included in a regression with auto returns. This is a very strong result, although perhaps not in the way that a casual interpretation would suggest. Since the wealth effect is driven by aggregate stock market values alone, and not the value of any particular sector of stocks, a casual interpretation of these results is that the coefficients on market returns should pick up the wealth effect. If so, these results would indicate that the wealth effect is too small to be found in the data.

This casual interpretation is false. To take an extreme counterexample, assume that auto industry stock returns are entirely determined by investors' forecasts of future aggregate consumption. Then given auto returns, no other variable will have any explanatory power for future consumption regardless of the structural relation between the stock market and consumption: auto returns will be a sufficient statistic.

In order to relax this extreme example somewhat, assume that the change in consumption from period $t-1$ to $t$, denoted $\Delta C_{t}$, consists of a component that is forecastable at time $t-1$, denoted $z_{t-1}$, and an unforecastable component, denoted $\theta_{t}$. The reduced form relations between the forecastable component and stock market returns (both aggregate and auto) are: 


$$
\begin{aligned}
& R_{m, t}=\alpha z_{t}+e_{1, t}+e_{3, t} \\
& R_{a, t}=\beta z_{t}+e_{2, t}+\gamma e_{3, t}
\end{aligned}
$$

In (3a) $-(3 \mathrm{~b}), \alpha$ and $\beta$ are greater than zero. The random variables $z_{t}$, $e_{1, t}, e_{2, t}$, and $e_{3, t}$ are assumed independent. Equations (3a)-(3b) make no assumptions about the forces driving consumption (there may or may not be a large wealth effect). They make only the very weak assumption that expected future changes in consumption and stock returns do not move in lockstep. Perhaps there are certain kinds of shocks to consumption that do not affect stock prices. More generally, this framework is consistent with many different types of shocks to consumption, some of which are positively associated with stock prices and some of which are negatively associated with stock prices. The coefficient $\gamma$ allows market returns and auto returns to be correlated apart from the correlation related to $z_{t}$.

Now consider regressing future changes in consumption on lagged market and auto stock returns. Given (3a)-(3b), the coefficient on the market return is

$$
\frac{\operatorname{Cov}\left(\Delta C_{t}, R_{m, t-1}\right) \operatorname{Var}\left(R_{a, t-1}\right)-\operatorname{Cov}\left(\Delta C_{t}, R_{a, t-1}\right) \operatorname{Cov}\left(R_{m, t-1}, R_{a, t-1}\right)}{\operatorname{Var}\left(R_{m, t-1}\right) \operatorname{Var}\left(R_{a, t-1}\right)-\left[\operatorname{Cov}\left(R_{m, t-1}, R_{a, t-1}\right)\right]^{2}}
$$

The denominator is positive. The numerator can be rewritten as

$$
\operatorname{Var}(z)\left(\alpha \operatorname{Var}\left(e_{2}\right)+\gamma^{2}\left(\alpha-\frac{\beta}{\gamma}\right) \operatorname{Var}\left(e_{3}\right)\right)
$$

As long as $\gamma>0$, the sign of the numerator is ambiguous, regardless of whether stock market wealth has an important effect on consumption. Thus we do not believe we can make any inferences about the structural relation between the stock market and consumption. Nevertheless, our results for consumption allow us to address the question of the structural relation between the stock market and investment. 


\section{Testing the Q-Theory of Investment}

Aggregate stock returns lead changes in aggregate investment. ${ }^{13}$ There are a number of possible explanations for this empirical regularity. It is an implication of Tobin's (1969) q-theory, combined with structural lags in firms' responses to $q$, along the lines of Kydland and Prescott's (1982) time-to-build model of investment. ${ }^{14}$ This relation is also an implication of a simple accelerator model of investment (Clark 1979), in which aggregate output determines firms' aggregate desired capital stocks. Because the stock market leads aggregate output, it also leads investment. Alternatively, firm managers may determine their optimal capital stock based on their forecasts of discounted future earnings. If the stock market is determined only by forecasts of these "fundamentals" then this theory is identical to $q$-theory in its empirical implications. If, however, the stock market is occasionally subject to "fads," then managers' forecasts of earnings will outperform the stock market as a forecaster of investment, as argued in Blanchard, Rhee and Summers (1993) and Morck, Shleifer, and Vishny (1990).

A number of recent papers have attempted to distinguish empirically the $q$-theory from the alternatives. Barro (1990), Morck, Shleifer, and Vishny (MSV) (1990), Blanchard, Rhee, and Summers (1993), and Galeotti and Schiantarelli (1994) attempt to separate the pure forecasting ability of the stock market from the "causal" (i.e., $q$-theory) effect of the market on investment. ${ }^{15}$

These papers typically use realizations of the forecasted variables to proxy for the forecasts, justifying this choice with the orthogonality of the forecast error. A very simple form of the typical regression is in (4).

13 For recent evidence, see Barro (1990), Blanchard, Rhee, and Summers (1993), Morck, Shleifer, and Vishny (1990), and Sensenbrenner (1991).

14 Zhou (1996) formally models the relation between investment and lagged $q$ using a time-to-build technology with adjustment costs.

15 These studies have mixed results. For example, Barro finds that even after controlling for fundamentals, lagged market returns have significant predictive ability and concludes that the market has an independent, real effect on investment. In contrast, MSV find that lagged returns do not explain investment after controlling for fundamentals. 


$$
\Delta I_{t}=b_{0}+b_{1} \Delta(\text { fundamental } t)+b_{2}(\text { aggregate stock return })_{t-1}+e_{t}
$$

However, regression equations such as (4) are flawed because the forecast error in the fundamental variable, although uncorrelated with lagged regressors, will typically be correlated with innovations in investment, and therefore correlated with $e_{t}$. Blanchard, Rhee, and Summers (1993) recognize this problem and use lagged instruments to construct a proxy for period t's fundamentals. They come to no strong conclusion about the extent to which fundamentals or aggregate stock returns determine investment. The problem is that it is difficult to find instruments that entirely capture the forecast power of the stock market. But unless such instruments are used, the forecasting ability of the stock market cannot be separated from the $q$-theory channel.

What is needed is a forecast of fundamentals that captures the forecasting power of aggregate stock returns. Our solution is to use auto industry stock returns. As shown in Table 1, lagged market returns have no explanatory power for either aggregate output or consumption when lagged auto returns are included as explanatory variables. We need an additional assumption to ensure that auto returns capture only the forecasting power of the stock market. In terms of eq. (3b), we must assume that the component of auto returns that is not in market returns, $e_{2, t}$, is unrelated to aggregate investment.

We use a simple accelerator model of investment with stock market variables added. The form of the model is

$$
\frac{I_{t}}{K_{t-1}}=b_{0}+\frac{b_{1}}{K_{t-1}}+\sum_{i=1}^{N} b_{i+1} \frac{C_{t-i}}{K_{t-1}}+\sum_{i=1}^{N} b_{m, i} \log P_{m, t-i}+\sum_{i=1}^{N} b_{a, i} \log P_{a, t-i}+\eta_{t}
$$

In (5), $I_{t}$ is gross investment in quarter $t, K_{t}$ is the net capital stock at the end of period $t, C_{t}$ is personal consumption expenditures in period $t$, and $P_{s, t}$ is the level of stock prices at the end of period $t$ for either the 
market as a whole $(s=m)$ or the auto industry $(s=a) \cdot{ }^{16}$ Investment data beginning in 1959:3 are in chain-weighted 1992 dollars. Earlier data is from the 1982 NIPA revision, spliced to the later data by equating 1959:3 values Year-end capital stock figures are from the Survey of Current Business. They are transformed from 1987 dollars to 1992 dollars using the chain-weighted GDP deflator. Quarter-end capital stock figures are interpolated from yearend values using the quarterly investment figures.

We estimate (5) in first-differences so that we can use stock returns instead of price levels. As many researchers have noted, investment is highly serially correlated. We therefore assume that the (differenced) error term follows an $\mathrm{AR}(2)$ process and use nonlinear least squares to estimate the parameters.

We separately consider two types of investment: Expenditures on producer durable equipment and expenditures on nonresidential structures. Table 7 reports the results for durable equipment. The regressions were estimated with four lags ( $N=4$ in eq. (5)), for consistency with the regressions estimated in this paper's previous sections. Column [1] presents the results for the accelerator model without any stock return variables, column [2] is the accelerator model combined with market returns, column [3] is the accelerator model with auto returns, and column [4] includes all explanatory variables.

The results in Table 7 confirm the standard result that market returns forecast investment, as does lagged consumption. Auto returns also forecast investment, but the combined explanatory power of auto returns and consumption (an adjusted $R^{2}$ of 32.4 percent) is lower than that of market returns and consumption (an adjusted $R^{2}$ of 34.9 percent). When both sets of returns are included, market returns retain explanatory power. The $F$ test that the market coefficients are all zero rejects the hypothesis at the $5 \%$ level, while the $F$-test that the sum of the coefficients equals zero rejects the

16 Because accelerator models of investment are essentially ad hoc, theory does not guide what sort of variables should be on the right-hand-side of (5). Clark (1979) uses private nonresidential business output, while Sensenbrenner (1991) uses GDP less investment. Our measure is closer to Sensenbrenner's in the sense that lagged investment is not present on the right-hand-side of (5) anywhere but in the lagged capital stock, where its role is simply as a heteroskedasticity adjustment. 
hypothesis at the $10 \%$ level. The point estimates imply that a one-standarddeviation quarterly market return (7.9 percent), holding all else constant, has a cumulative effect on investment of 0.18 percent of the existing capital stock. This does not seem economically insignificant. For example, this figures implies that a one-standard-deviation increase in the market return in the final quarter of 1993 would have by itself increased durable equipment investment in 1994 by 1.12 percent.

Surprisingly, the statistical significance of auto returns disappears in the presence of market returns. Taken literally, this suggests that given lagged consumption, the relation between the stock market and future investment is driven by $q$-theory effects. We prefer to interpret this result cautiously because we are estimating a reduced-form model without the benefit of a formal theory linking investment, market returns, and auto returns. Nonetheless, these results certainly do not support the notion that the stock market is simply a sideshow.

The results for nonresidential structures are much less clear than those for durable equipment. When four lags of explanatory variables were used, neither market returns nor auto returns had significant explanatory power when they were separately included in the regression with consumption. In other words, there was no relation between the stock market and structures investment. The microeconomic evidence of Montgomery (1995) indicates that nonresidential structures take five to six quarters to build, so we extended our lag length to six and reestimated the regressions. The results are in Table 8.

For all specifications, changes in the growth of nonresidential structures expenditures are less predictable than changes in the growth of durable equipment expenditures; the estimated coefficients are also less statistically significant. For example, in column [2] we see that while the sum of the market return coefficients is greater than zero at the $5 \%$ level, the restriction that all six of the coefficients are identically zero cannot be rejected. A comparison of columns [2] and [3] reveals that auto returns are slightly better (in an adjusted $R^{2}$ sense) than market returns at forecasting durable equipment expenditures. When both market and auto returns are included in the regression (column [4]), no hypothesis of interest can be rejected at any conventional significance level. 
Obviously, we are unable to draw any strong conclusions from Table 8 alone. However, the marked contrast between Tables 7 and 8 indicate that models of investment would do well to consider possible reasons why different types of investment respond differently to the stock market. On balance, a $q$-theory effect appears evident in durable equipment investment, but any such effect is obscured in nonresidential structures investment.

\section{Conclusion}

Our empirical work indicates that lagged stock returns to the auto industry are better predictors of aggregate output and consumption than are lagged aggregate market returns. In fact, market returns have no explanatory power when they are included in regressions with auto industry returns. In addition, auto returns contain information concerning future growth rates of consumption on nondurables and services that is not contained in either lagged growth rates of consumption or in lagged growth rates of aggregate income. This predictive power does not come from the ability of auto returns to predict future aggregate income, in contrast to Campbell and Mankiw's (1991) model of rule-of-thumb consumers.

We believe that auto industry stock returns forecast macroeconomic variables because the fortunes of this sector are closely tied to the business cycle, or what Stock and Watson (1989) call the unobserved state of the economy. Investors have information about the future state of the business cycle, and use that information to bid up or down the price of auto industry stocks. Our evidence for this interpretation is that auto industry stocks outperform stocks with high consumption betas in forecasting future consumption growth, and that in each of the past four decades, auto returns have outperformed market returns in forecasting output.

In contrast to the results for output and consumption, we find market returns are superior to auto returns in forecasting future changes in durable equipment investment. We argue that this evidence is supportive of the $q$ theory of investment, at least for producers' durable equipment investment. The inconclusive results for nonresidential structures indicate that this interpretation may not be valid for this type of investment.

The limited lesson of this paper is that economic forecasters should seriously consider including stock returns to the automotive sector in their 
collection of forecasting tools. A broader and more important lesson is that there is an abundance of information in stock market prices that can and should be used in constructing and evaluating macroeconomic models. 


\section{References}

Barro, Robert J., 1990, "The stock market and investment", Review of Financial Studies 3, 115-32.

Blanchard, Olivier, Changyong Rhee, and Lawrence Summers, 1993, "The stock market, profit, and investment," Quarterly Journal of Economics 432, 115-136.

Bosworth, Barry, 1975, "The stock market and the economy," Brookings Papers on Economic Activity 3, 257-90.

Campbell, John Y., and N. Gregory Mankiw, 1990, "Consumption, income, and interest rates: Reinterpreting the time series evidence," NBER Macroeconomic Annual 185-216.

Clark, Peter K., 1979, "Investment in the 1970s: Theory, performance, and prediction," Brookings Papers on Economic Activity 1, 73-124.

Estrella, Arturo, and Frederic S. Mishkin, 1996, "Predicting U.S. recessions: Financial variables as leading indicators," Working paper, Federal Reserve Bank of New York (New York, NY).

Fama, Eugene F., 1981, "Stock returns, real activity, inflation and money," American Economic Review 71, 545-65.

Fischer, Stanley, and Robert C. Merton, 1984, "Macroeconomics and finance: The role of the stock market," Carnegie-Rochester Conference Series on Public Policy 21, 75-88.

Galeotti, Marzio, and Fabio Schiantarelli, 1994, "Stock market volatility and investment: Do only fundamentals matter?" Economica 61, 147165.

Hall, Robert E., 1978, "Stochastic implications of the life cycle permanent income hypothesis: Theory and evidence," Journal of Political Economy $86,971-87$. 
Kydland, Finn E., and Edward C. Prescott, 1982, "Time-to-build and aggregate fluctuations," Econometrica 50, 1345-1370.

Mankiw, N. Gregory, 1982, "Hall's consumption hypothesis and durable goods," Journal of Monetary Economics 10, 417-425.

Montgomery, Michael R., 1995, " 'Time-to-build' completion patterns for nonresidential structures, 1961-1991," Economic Letters 48, 155-163.

Moore, George H., 1983, Business cycles, inflation, and forecasting, Cambridge: Ballinger.

Morck, Randall, Andrei Shleifer and Robert Vishny, 1990, "The stock market and investment: Is the market a sideshow?" Brookings Papers on Economic Activity 2, 157-215.

Nelson, Charles R., and Richard Startz 1990, "The Distribution of the instrumental variable and its t-ratio when the instrument is a poor one," Journal of Business 63 (1 pt. 2), S125-S140.

Sensenbrenner, Gabriel, 1991, "Aggregate investment, the stock market and the Q model: Robust results for six OECD countries," European Economic Review 35, 769-832.

Stock, James H., and Mark W. Watson, 1989, "New indexes of leading and coincident indicators," NBER Macroeconomics Annual, 351-94.

Stock, James H., and Mark W. Watson, 1993, "A procedure for predicting recessions with leading indicators: Econometric issues and recent experience," in Business cycles, indicators, and forecasting, James H. Stock and Mark W. Watson, editors, University of Chicago Press (Chicago, IL).

Tobin, James, 1969, "A general equilibrium approach to monetary theory," Journal of Money, Credit and Banking 1, 15-29.

Working, Holbrook, 1960, "Note on the correlation of first differences of averages in a random chain," Econometrica 28, 916-918.

Zhou, Chunsheng, 1996, "Time-to-build and investment," Working paper, Federal Reserve Board (Washington, DC). 
Table 1

Forecasting Output and Consumption with Aggregate and Auto Industry Stock Returns

First differences of log real quarterly gross domestic product (GDP) and personal consumption expenditures (PCE) are regressed on four lags each of quarterly stock returns to the entire market and to the automotive sector. The regressions are estimated with ordinary least-squares from 1954:1 through 1996:1. $T$-statistics are in parentheses and $p$-values of $\chi^{2}$ statistics are in brackets. All are adjusted for generalized heteroskedasticity and one lag of moving average residuals.

\begin{tabular}{|c|c|c|c|c|c|c|}
\hline $\begin{array}{l}\text { Explanatory } \\
\text { variable }\end{array}$ & [1] & $\begin{array}{r}\text { GDP } \\
{[2]}\end{array}$ & {$[3]$} & [4] & $\begin{array}{r}\mathrm{PCE} \\
{[5]}\end{array}$ & [6] \\
\hline Market lag 1 & $\begin{array}{r}0.0329 \\
(3.54)\end{array}$ & - & $\begin{array}{r}0.0130 \\
(1.13)\end{array}$ & $\begin{array}{r}0.0286 \\
(3.51)\end{array}$ & - & $\begin{array}{r}0.0104 \\
(1.09)\end{array}$ \\
\hline Market lag 2 & $\begin{array}{r}0.0357 \\
(3.92)\end{array}$ & - & $\begin{array}{r}0.0091 \\
(0.69)\end{array}$ & $\begin{array}{r}0.0235 \\
(3.69)\end{array}$ & - & $\begin{array}{r}0.0028 \\
(0.30)\end{array}$ \\
\hline Market lag 3 & $\begin{array}{r}0.0184 \\
(2.18)\end{array}$ & - & $\begin{array}{r}-0.0016 \\
(0.14)\end{array}$ & $\begin{array}{r}0.0003 \\
(0.06)\end{array}$ & - & $\begin{array}{r}-0.0130 \\
(1.48)\end{array}$ \\
\hline Market lag 4 & $\begin{array}{r}0.0161 \\
(2.43)\end{array}$ & - & $\begin{array}{r}-0.0017 \\
(0.16)\end{array}$ & $\begin{array}{r}0.0207 \\
(3.60)\end{array}$ & - & $\begin{array}{r}-0.0025 \\
(0.29)\end{array}$ \\
\hline Auto lag 1 & - & $\begin{array}{c}0.0264 \\
(4.19)\end{array}$ & $\begin{array}{c}0.0187 \\
(2.25)\end{array}$ & - & $\begin{array}{r}0.0221 \\
(4.69)\end{array}$ & $\begin{array}{r}0.0164 \\
(2.62)\end{array}$ \\
\hline Auto lag 2 & - & $\begin{array}{r}0.0290 \\
(4.45)\end{array}$ & $\begin{array}{r}0.0242 \\
(2.48)\end{array}$ & - & $\begin{array}{r}0.0194 \\
(4.06)\end{array}$ & $\begin{array}{r}0.0189 \\
(2.45)\end{array}$ \\
\hline Auto lag 3 & - & $\begin{array}{r}0.0158 \\
(2.59)\end{array}$ & $\begin{array}{r}0.0167 \\
(1.89)\end{array}$ & - & $\begin{array}{c}0.0036 \\
(0.97)\end{array}$ & $\begin{array}{r}0.0108 \\
(1.88)\end{array}$ \\
\hline Auto lag 4 & - & $\begin{array}{c}0.0119 \\
(2.32)\end{array}$ & $\begin{array}{r}0.0130 \\
(1.50)\end{array}$ & - & $\begin{array}{c}0.0176 \\
(3.94)\end{array}$ & $\begin{array}{r}0.0192 \\
(2.77)\end{array}$ \\
\hline Adjusted $R^{2}$ & 0.178 & 0.224 & 0.212 & 0.189 & 0.252 & 0.251 \\
\hline $\begin{array}{l}\chi^{2}(4) \text { test that all } \\
\text { market coefs equal } 0\end{array}$ & $\begin{array}{l}47.16 \\
{[.000]}\end{array}$ & & $\begin{array}{r}2.31 \\
{[.679]}\end{array}$ & $\begin{array}{l}41.66 \\
{[.000]}\end{array}$ & & $\begin{array}{r}4.20 \\
{[.380]}\end{array}$ \\
\hline $\begin{array}{l}\chi^{2}(1) \text { test that sum } \\
\text { of market coefs equals } 0\end{array}$ & $\begin{array}{l}43.32 \\
{[.000]}\end{array}$ & & $\begin{array}{c}0.52 \\
{[.470]}\end{array}$ & $\begin{array}{l}32.84 \\
{[.000]}\end{array}$ & & $\begin{array}{r}0.01 \\
{[.911]}\end{array}$ \\
\hline $\begin{array}{l}\chi^{2}(4) \text { test that all } \\
\text { auto coefs equal } 0\end{array}$ & & $\begin{array}{l}50.99 \\
{[.000]}\end{array}$ & $\begin{array}{l}12.40 \\
{[.015]}\end{array}$ & & $\begin{array}{l}55.90 \\
{[.000]}\end{array}$ & $\begin{array}{l}17.47 \\
{[.002]}\end{array}$ \\
\hline $\begin{array}{l}\chi^{2}(1) \text { test that sum } \\
\text { of auto coefs equals } 0\end{array}$ & & $\begin{array}{l}49.05 \\
{[.000]}\end{array}$ & $\begin{array}{l}11.08 \\
{[.001]}\end{array}$ & & $\begin{array}{l}52.20 \\
{[.000]}\end{array}$ & $\begin{array}{l}16.21 \\
{[.000]}\end{array}$ \\
\hline
\end{tabular}


Table 2

Forecasting Durable Good Expenditures with Aggregate and Auto Industry Stock Returns

First differences of log real quarterly durable goods expenditures are regressed on four lags each of quarterly stock returns to the entire market and to the automotive sector. The regressions are estimated with ordinary least-squares from 1954:1 through 1996:1. $T$-statistics are in parentheses and $p$-values of $\chi^{2}$ statistics are in brackets. All are adjusted for generalized heteroskedasticity and one lag of moving average residuals.

\begin{tabular}{|c|c|c|c|c|c|c|}
\hline \multirow{2}{*}{$\begin{array}{l}\begin{array}{l}\text { Explanatory } \\
\text { variable }\end{array} \\
\text { Market lag } 1\end{array}$} & \multicolumn{3}{|c|}{$\begin{array}{lll} & \text { All Durables } & \\
{[1]} & {[2]} & {[3]}\end{array}$} & \multicolumn{3}{|c|}{$\begin{array}{ccc}\text { Motor Vehicles/Parts } & \\
{[4]} & {[6]}\end{array}$} \\
\hline & $\begin{array}{r}0.1147 \\
(3.03)\end{array}$ & - & $\begin{array}{c}0.0806 \\
(1.64)\end{array}$ & $\begin{array}{r}0.1880 \\
(2.72)\end{array}$ & - & $\begin{array}{r}0.1442 \\
(1.50)\end{array}$ \\
\hline Market lag 2 & $\begin{array}{r}0.1301 \\
(3.34)\end{array}$ & - & $\begin{array}{c}0.0383 \\
(0.75)\end{array}$ & $\begin{array}{r}0.2405 \\
(2.64)\end{array}$ & - & $\begin{array}{r}0.0612 \\
(0.57)\end{array}$ \\
\hline Market lag 3 & $\begin{array}{r}-0.0023 \\
(0.07)\end{array}$ & - & $\begin{array}{r}-0.0372 \\
(0.83)\end{array}$ & $\begin{array}{r}-0.0366 \\
(0.51)\end{array}$ & - & $\begin{array}{r}-0.0699 \\
(0.70)\end{array}$ \\
\hline Market lag 4 & $\begin{array}{r}0.0664 \\
(2.26)\end{array}$ & - & $\begin{array}{r}-0.0380 \\
(0.96)\end{array}$ & $\begin{array}{r}0.1056 \\
(1.87)\end{array}$ & - & $\begin{array}{r}-0.0722 \\
(0.90)\end{array}$ \\
\hline Auto lag 1 & - & $\begin{array}{r}0.0711 \\
(3.56)\end{array}$ & $\begin{array}{r}0.0255 \\
(0.85)\end{array}$ & - & $\begin{array}{r}0.1092 \\
(2.86)\end{array}$ & $\begin{array}{r}0.0283 \\
(0.44)\end{array}$ \\
\hline Auto lag 2 & - & $\begin{array}{c}0.1080 \\
(3.88)\end{array}$ & $\begin{array}{c}0.0903 \\
(2.27)\end{array}$ & - & $\begin{array}{r}0.2060 \\
(3.47)\end{array}$ & $\begin{array}{r}0.1786 \\
(2.41)\end{array}$ \\
\hline Auto lag 3 & - & $\begin{array}{r}0.0002 \\
(0.01)\end{array}$ & $\begin{array}{r}0.0232 \\
(0.76)\end{array}$ & - & $\begin{array}{r}-0.0326 \\
(0.72)\end{array}$ & $\begin{array}{r}0.0108 \\
(0.17)\end{array}$ \\
\hline Auto lag 4 & - & $\begin{array}{r}0.0729 \\
(2.96)\end{array}$ & $\begin{array}{r}0.0945 \\
(2.80)\end{array}$ & - & $\begin{array}{r}0.1249 \\
(2.75)\end{array}$ & $\begin{array}{r}0.1657 \\
(2.50)\end{array}$ \\
\hline Adjusted $R^{2}$ & 0.168 & 0.205 & 0.217 & 0.129 & 0.166 & 0.171 \\
\hline $\begin{array}{l}\chi^{2}(4) \text { test that all } \\
\text { market coefs equal } 0\end{array}$ & $\begin{array}{l}30.89 \\
{[.000]}\end{array}$ & & $\begin{array}{r}5.90 \\
{[.207]}\end{array}$ & $\begin{array}{l}27.15 \\
{[.000]}\end{array}$ & & $\begin{array}{r}4.47 \\
{[.346]}\end{array}$ \\
\hline $\begin{array}{l}\chi^{2}(1) \text { test that sum } \\
\text { of market coefs equals } 0\end{array}$ & $\begin{array}{l}26.08 \\
{[.000]}\end{array}$ & & $\begin{array}{r}0.20 \\
{[.653]}\end{array}$ & $\begin{array}{l}21.10 \\
{[.000]}\end{array}$ & & $\begin{array}{r}0.11 \\
{[.737]}\end{array}$ \\
\hline $\begin{array}{l}\chi^{2}(4) \text { test that all } \\
\text { auto coefs equal } 0\end{array}$ & & $\begin{array}{l}33.62 \\
{[.000]}\end{array}$ & $\begin{array}{l}13.33 \\
{[.001]}\end{array}$ & & $\begin{array}{l}29.31 \\
{[.000]}\end{array}$ & $\begin{array}{l}12.14 \\
{[.016]}\end{array}$ \\
\hline $\begin{array}{l}\chi^{2}(1) \text { test that sum } \\
\text { of auto coefs equals } 0\end{array}$ & & $\begin{array}{l}31.22 \\
{[.000]}\end{array}$ & $\begin{array}{r}9.39 \\
{[.002]}\end{array}$ & & $\begin{array}{l}25.24 \\
{[.000]}\end{array}$ & $\begin{array}{r}6.63 \\
{[.010]}\end{array}$ \\
\hline
\end{tabular}


Table 3

Forecasting Nondurables and Services Expenditures with Aggregate and Auto Industry Stock Returns

First differences of log real quarterly expenditures on nondurables and services are regressed on four lags each of quarterly stock returns to the entire market and to the automotive sector. The regressions are estimated with ordinary least-squares from 1954:1 through 1996:1. T-statistics are in parentheses and $p$-values of $\chi^{2}$ statistics are in brackets. All are adjusted for generalized heteroskedasticity and one lag of moving average residuals.

\begin{tabular}{|c|c|c|c|}
\hline $\begin{array}{l}\text { Explanatory } \\
\text { variable }\end{array}$ & {$[1]$} & {$[2]$} & {$[3]$} \\
\hline Market lag 1 & $\begin{array}{r}0.0153 \\
(3.29)\end{array}$ & - & $\begin{array}{r}-0.0008 \\
(0.13)\end{array}$ \\
\hline Market lag 2 & $\begin{array}{r}0.0080 \\
(2.15)\end{array}$ & - & $\begin{array}{r}-0.0023 \\
(0.43)\end{array}$ \\
\hline Market lag 3 & $\begin{array}{r}0.0012 \\
(0.29)\end{array}$ & - & $\begin{array}{r}-0.0088 \\
(1.35)\end{array}$ \\
\hline Market lag 4 & $\begin{array}{r}0.0136 \\
(3.78)\end{array}$ & - & $\begin{array}{r}0.0033 \\
(0.57)\end{array}$ \\
\hline Auto lag 1 & - & $\begin{array}{r}0.0147 \\
(4.39)\end{array}$ & $\begin{array}{r}0.0153 \\
(3.18)\end{array}$ \\
\hline Auto lag 2 & - & $\begin{array}{c}0.0064 \\
(2.02)\end{array}$ & $\begin{array}{r}0.0083 \\
(1.71)\end{array}$ \\
\hline Auto lag 3 & - & $\begin{array}{c}0.0044 \\
(1.74)\end{array}$ & $\begin{array}{r}0.0088 \\
(2.14)\end{array}$ \\
\hline Auto lag 4 & - & $\begin{array}{c}0.0089 \\
(3.22)\end{array}$ & $\begin{array}{r}0.0073 \\
(1.52)\end{array}$ \\
\hline Adjusted $R^{2}$ & 0.102 & 0.163 & 0.154 \\
\hline $\begin{array}{l}\chi^{2}(4) \text { test that all } \\
\text { market coefs equal } 0\end{array}$ & $\begin{array}{l}27.10 \\
{[.000]}\end{array}$ & & $\begin{array}{r}2.80 \\
{[.592]}\end{array}$ \\
\hline $\begin{array}{l}\chi^{2}(1) \text { test that sum } \\
\text { of market coefs equals } 0\end{array}$ & $\begin{array}{l}20.40 \\
{[.000]}\end{array}$ & & $\begin{array}{r}0.39 \\
{[.532]}\end{array}$ \\
\hline $\begin{array}{l}\chi^{2}(4) \text { test that all } \\
\text { auto coefs equal } 0\end{array}$ & & $\begin{array}{l}34.22 \\
{[.000]}\end{array}$ & $\begin{array}{l}13.34 \\
{[.001]}\end{array}$ \\
\hline $\begin{array}{l}\chi^{2}(1) \text { test that sum } \\
\text { of auto coefs equals } 0\end{array}$ & & $\begin{array}{l}31.07 \\
{[.000]}\end{array}$ & $\begin{array}{l}11.63 \\
{[.001]}\end{array}$ \\
\hline
\end{tabular}


Table 4

Forecasting Nondurables and Services Expenditures

First differences of log real quarterly expenditures on nondurables and services are regressed on its own lags two through six and lags two through four of quarterly stock returns to the automotive sector. The regressions are estimated with ordinary least-squares from 1954:1 through 1996:1. $T$-statistics are in parentheses and $p$-values of $\chi^{2}$ statistics are in brackets. All are adjusted for generalized heteroskedasticity and one lag of moving average residuals.

\begin{tabular}{|c|c|c|c|}
\hline $\begin{array}{l}\text { Explanatory } \\
\text { variable }\end{array}$ & {$[1]$} & {$[2]$} & {$[3]$} \\
\hline Own lag 2 & - & $\begin{array}{r}0.1421 \\
(1.88)\end{array}$ & $\begin{array}{r}0.0852 \\
(1.06)\end{array}$ \\
\hline Own lag 3 & - & $\begin{array}{r}0.2192 \\
(2.91)\end{array}$ & $\begin{array}{r}0.1947 \\
(2.36)\end{array}$ \\
\hline Own lag 4 & - & $\begin{array}{r}0.0484 \\
(0.69)\end{array}$ & $\begin{array}{r}0.0280 \\
(0.41)\end{array}$ \\
\hline Own lag 5 & - & $\begin{array}{r}-0.1773 \\
(2.14)\end{array}$ & $\begin{array}{r}-0.1608 \\
(1.79)\end{array}$ \\
\hline Own lag 6 & - & $\begin{array}{r}0.1096 \\
(1.68)\end{array}$ & $\begin{array}{r}0.1642 \\
(2.45)\end{array}$ \\
\hline Auto lag 2 & $\begin{array}{r}0.0075 \\
(2.26)\end{array}$ & - & $\begin{array}{r}0.0082 \\
(2.27)\end{array}$ \\
\hline Auto lag 3 & $\begin{array}{r}0.0026 \\
(0.90)\end{array}$ & - & $\begin{array}{r}-0.0008 \\
(0.26)\end{array}$ \\
\hline Auto lag 4 & $\begin{array}{r}0.0095 \\
(3.30)\end{array}$ & - & $\begin{array}{r}0.0059 \\
(1.98)\end{array}$ \\
\hline Adjusted $R^{2}$ & 0.058 & 0.093 & 0.118 \\
\hline $\begin{array}{l}\chi^{2}(5) \text { test that all } \\
\text { own coefs equal } 0\end{array}$ & & $\begin{array}{l}25.01 \\
{[.000]}\end{array}$ & $\begin{array}{l}22.00 \\
{[.001]}\end{array}$ \\
\hline $\begin{array}{l}\chi^{2}(1) \text { test that sum } \\
\text { of own coefs equals } 0\end{array}$ & & $\begin{array}{r}6.76 \\
{[.009]}\end{array}$ & $\begin{array}{r}5.96 \\
{[.015]}\end{array}$ \\
\hline $\begin{array}{l}\chi^{2}(3) \text { test that all } \\
\text { auto coefs equal } 0\end{array}$ & $\begin{array}{l}14.28 \\
{[.003]}\end{array}$ & & $\begin{array}{r}8.51 \\
{[.037]}\end{array}$ \\
\hline $\begin{array}{l}\chi^{2}(1) \text { test that sum } \\
\text { of auto coefs equals } 0\end{array}$ & $\begin{array}{l}11.87 \\
{[.001]}\end{array}$ & & $\begin{array}{r}4.31 \\
{[.038]}\end{array}$ \\
\hline
\end{tabular}


Table 5

Forecasting Personal Income with Aggregate and Auto Industry Stock Returns

First differences of log real personal income are regressed on lags two through four of quarterly stock returns to the entire market and to the automotive sector. The regressions are estimated with ordinary least-squares from 1954:1 through 1996:1. $T$-statistics are in parentheses and $p$-values of $\chi^{2}$ statistics are in brackets. All are adjusted for generalized heteroskedasticity and one lag of moving average residuals. two through four of quarterly stock returns to the automotive sector. The regressions are estimated with ordinary least-squares from 1954:1 through 1996:1. $T$-statistics are in parentheses and $p$-values of $\chi^{2}$ statistics are in brackets. All are adjusted for generalized heteroskedasticity and one lag of moving average residuals.

\begin{tabular}{|c|c|c|}
\hline $\begin{array}{l}\text { Explanatory } \\
\text { variable }\end{array}$ & {$[1]$} & {$[2]$} \\
\hline Market lag 2 & $\begin{array}{r}0.0263 \\
(3.49)\end{array}$ & - \\
\hline Market lag 3 & $\begin{array}{r}-0.0047 \\
(0.37)\end{array}$ & - \\
\hline Market lag 4 & $\begin{array}{r}0.0213 \\
(2.46)\end{array}$ & - \\
\hline Auto lag 2 & - & $\begin{array}{r}0.0173 \\
(2.53)\end{array}$ \\
\hline Auto lag 3 & - & $\begin{array}{r}-0.0001 \\
(0.01)\end{array}$ \\
\hline Auto lag 4 & - & $\begin{array}{r}0.0153 \\
(2.45)\end{array}$ \\
\hline Adjusted $R^{2}$ & 0.055 & 0.048 \\
\hline $\begin{array}{l}\chi^{2}(3) \text { test that all } \\
\text { market coefs equal } 0\end{array}$ & $\begin{array}{l}19.17 \\
{[.000]}\end{array}$ & \\
\hline $\begin{array}{l}\chi^{2}(1) \text { test that sum } \\
\text { of market coefs equals } 0\end{array}$ & $\begin{array}{r}7.41 \\
{[.006]}\end{array}$ & \\
\hline $\begin{array}{l}\chi^{2}(3) \text { test that all } \\
\text { auto coefs equal } 0\end{array}$ & & $\begin{array}{l}13.24 \\
{[.004]}\end{array}$ \\
\hline $\begin{array}{l}\chi^{2}(1) \text { test that sum } \\
\text { of auto coefs equals } 0\end{array}$ & & $\begin{array}{r}6.41 \\
{[.011]}\end{array}$ \\
\hline
\end{tabular}


Table 6

Root Mean Squared Errors of Out of Sample Forecasts of Output

For all quarters $t$ from 1960:1 through 1995:4, first differences of log real quarterly GDP are regressed on the explanatory variables from 1954:1 through quarter $t$. Each regression is used to generate a forecast of quarter $t+1$ 's log change in real GDP. The square root of the mean squared difference between the actual log change and the forecasted log change is reported below, by decade. All values are in percent.

\begin{tabular}{lcccc}
\hline Explanatory variables & $1960: 1-1969: 4$ & $1970: 1-1979: 4$ & $1980: 1-1989: 4$ & $1990: 1-1996: 1$ \\
\hline $\begin{array}{l}\text { Constant } \\
\begin{array}{l}\text { Constant, four lags of } \\
\text { market returns }\end{array}\end{array}$ & 0.982 & 1.105 & 0.989 & 0.636 \\
$\begin{array}{l}\text { Constant, four lags of } \\
\text { auto returns }\end{array}$ & 0.967 & 1.026 & 0.895 & 0.595 \\
\hline
\end{tabular}


Table 7

\section{Forecasting Changes in Producer Durable Equipment Expenditures}

$$
\begin{gathered}
\Delta\left(\frac{I_{t}}{K_{t-1}}\right)=\Delta\left(\frac{b_{0}}{K_{t-1}}\right)+\sum_{i=1}^{4} b_{i} \Delta\left(\frac{C_{t-i}}{K_{t-1}}\right)+\sum_{i=1}^{4} b_{m, i} R_{m, t-i}+\sum_{i=1}^{4} b_{a, i} R_{a, t-i}+e_{t} \\
e_{t}=\theta_{1} e_{t-1}+\theta_{2} e_{t-2}+\eta_{t}
\end{gathered}
$$

Producers' durable equipment investment during quarter $t$ is $I_{t}$ and personal consumption expenditures is $C_{t}$. The end-of-period net stock of durable equipment is $K_{t}$. All are in 1992 dollars. The return to the CRSP value-weighted index during quarter $t$ less the three-month Treasury bill yield prevailing at the end of quarter $t-1$ is $R_{m, t}$. The stock return to the automotive industry, $R_{a, t}$, is defined similarly. Estimation is with nonlinear least squares. $T$-statistics are in parentheses and $p$-values of $F$ tests are in brackets.

\begin{tabular}{|c|c|c|c|c|}
\hline Coefficient & {$[1]$} & {$[2]$} & {$[3]$} & {$[4]$} \\
\hline $\begin{array}{l}\text { Sum of coefs on } \\
\text { lagged consumption }\end{array}$ & $\begin{array}{r}0.1958 \\
(5.12)\end{array}$ & $\begin{array}{c}0.1283 \\
(3.05)\end{array}$ & $\begin{array}{r}0.1001 \\
(2.22)\end{array}$ & $\begin{array}{r}0.1110 \\
(2.39)\end{array}$ \\
\hline Market lag 1 & - & $\begin{array}{r}0.0047 \\
(1.54)\end{array}$ & - & $\begin{array}{r}0.0000 \\
(0.00)\end{array}$ \\
\hline Market lag 2 & - & $\begin{array}{r}0.0181 \\
(5.60)\end{array}$ & - & $\begin{array}{r}0.0142 \\
(2.93)\end{array}$ \\
\hline Market lag 3 & - & $\begin{array}{c}0.0044 \\
(1.35)\end{array}$ & - & $\begin{array}{r}0.0053 \\
(1.09)\end{array}$ \\
\hline Market lag 4 & - & $\begin{array}{r}0.0079 \\
(2.44)\end{array}$ & - & $\begin{array}{r}0.0048 \\
(0.98)\end{array}$ \\
\hline Auto lag 1 & - & - & $\begin{array}{r}0.0057 \\
(2.42)\end{array}$ & $\begin{array}{r}0.0046 \\
(1.23)\end{array}$ \\
\hline Auto lag 2 & - & - & $\begin{array}{r}0.0116 \\
(4.59)\end{array}$ & $\begin{array}{r}0.0035 \\
(0.95)\end{array}$ \\
\hline Auto lag 3 & - & - & $\begin{array}{r}0.0022 \\
(0.86)\end{array}$ & $\begin{array}{r}-0.0011 \\
(0.28)\end{array}$ \\
\hline Auto lag 4 & - & - & $\begin{array}{r}0.0059 \\
(2.40)\end{array}$ & $\begin{array}{r}0.0027 \\
(0.74)\end{array}$ \\
\hline Adjusted $R^{2}$ & 0.233 & 0.349 & 0.324 & 0.348 \\
\hline $\begin{array}{l}F \text { test that all } \\
\text { market coefs equal } 0\end{array}$ & & $\begin{array}{r}8.05 \\
{[.000]}\end{array}$ & & $\begin{array}{r}2.46 \\
{[.048]}\end{array}$ \\
\hline $\begin{array}{l}F \text { test that sum } \\
\text { of market coefs equals } 0\end{array}$ & & $\begin{array}{l}18.02 \\
{[.000]}\end{array}$ & & $\begin{array}{r}3.01 \\
{[.085]}\end{array}$ \\
\hline $\begin{array}{l}F \text { test that all } \\
\text { auto coefs equal } 0\end{array}$ & & & $\begin{array}{r}6.27 \\
{[.000]}\end{array}$ & $\begin{array}{r}0.90 \\
{[.466]}\end{array}$ \\
\hline $\begin{array}{l}F \text { test that sum } \\
\text { of auto coefs equals } 0\end{array}$ & & & $\begin{array}{l}14.17 \\
{[.000]}\end{array}$ & $\begin{array}{r}0.76 \\
{[.386]}\end{array}$ \\
\hline
\end{tabular}
Estimation is from 1954:1 through 1995:1. 
Table 8

Forecasting Changes in Nonresidential Structures Expenditures

$$
\begin{gathered}
\Delta\left(\frac{I_{t}}{K_{t-1}}\right)=\Delta\left(\frac{b_{0}}{K_{t-1}}\right)+\sum_{i=1}^{4} b_{i} \Delta\left(\frac{C_{t-i}}{K_{t-1}}\right)+\sum_{i=1}^{4} b_{m, i} R_{m, t-i}+\sum_{i=1}^{4} b_{a, i} R_{a, t-i}+e_{t} \\
e_{t}=\theta_{1} e_{t-1}+\theta_{2} e_{t-2}+\eta_{t}
\end{gathered}
$$

Nonresidential structures investment during quarter $t$ is $I_{t}$ and personal consumption expenditures is $C_{t}$. The end-of-period net stock of nonresidential structures is $K_{t}$. All are in 1992 dollars. The return to the CRSP value-weighted index during quarter $t$ less the three-month Treasury bill yield prevailing at the end of quarter $t-1$ is $R_{m, t}$. The stock return to the automotive industry, $R_{a, t}$, is defined similarly. Estimation is with nonlinear least squares. $T$-statistics are in parentheses and $p$-values of $F$ tests are in brackets.

\begin{tabular}{|c|c|c|c|c|}
\hline Coefficient & {$[1]$} & {$[2]$} & {$[3]$} & {$[4]$} \\
\hline $\begin{array}{l}\text { Sum of coefs on } \\
\text { lagged consumption }\end{array}$ & $\begin{array}{r}0.1061 \\
(2.76)\end{array}$ & $\begin{array}{c}0.0516 \\
(1.25)\end{array}$ & $\begin{array}{c}0.0958 \\
(2.65)\end{array}$ & $\begin{array}{r}0.1059 \\
(2.87)\end{array}$ \\
\hline Market lag 1 & - & $\begin{array}{r}-0.0005 \\
(0.27)\end{array}$ & - & $\begin{array}{r}0.0022 \\
(0.72)\end{array}$ \\
\hline Market lag 2 & - & $\begin{array}{c}0.0030 \\
(1.48)\end{array}$ & - & $\begin{array}{r}0.0046 \\
(1.45)\end{array}$ \\
\hline Market lag 3 & - & $\begin{array}{c}0.0054 \\
(2.47)\end{array}$ & - & $\begin{array}{r}0.0032 \\
(0.98)\end{array}$ \\
\hline Market lag 4 & - & $\begin{array}{r}0.0032 \\
(1.46)\end{array}$ & - & $\begin{array}{r}0.0053 \\
(1.58)\end{array}$ \\
\hline Market lag 5 & - & $\begin{array}{c}0.0026 \\
(1.26)\end{array}$ & - & $\begin{array}{r}0.0016 \\
(0.49)\end{array}$ \\
\hline Market lag 6 & - & $\begin{array}{r}0.0041 \\
(2.00)\end{array}$ & - & $\begin{array}{r}0.0005 \\
(0.16)\end{array}$ \\
\hline Auto lag 1 & - & - & $\begin{array}{r}-0.0008 \\
(0.54)\end{array}$ & $\begin{array}{r}-0.0024 \\
(1.05)\end{array}$ \\
\hline Auto lag 2 & - & - & $\begin{array}{r}0.0020 \\
(1.29)\end{array}$ & $\begin{array}{r}-0.0010 \\
(0.41)\end{array}$ \\
\hline Auto lag 3 & - & - & $\begin{array}{r}0.0045 \\
(2.64)\end{array}$ & $\begin{array}{r}0.0021 \\
(0.78)\end{array}$ \\
\hline Auto lag 4 & - & - & $\begin{array}{c}0.0013 \\
(0.76)\end{array}$ & $\begin{array}{r}-0.0019 \\
(0.73)\end{array}$ \\
\hline Auto lag 5 & - & - & $\begin{array}{r}0.0022 \\
(1.35)\end{array}$ & $\begin{array}{r}0.0011 \\
(0.44)\end{array}$ \\
\hline Auto lag 6 & - & - & $\begin{array}{c}0.0035 \\
(1.07)\end{array}$ & $\begin{array}{r}0.0033 \\
(1.43)\end{array}$ \\
\hline
\end{tabular}
Estimation is from 1954:1 through 1995:1.

Table 8 continues... 
Table 8 (continued)

Forecasting Changes in Nonresidential Structures Expenditures

\begin{tabular}{|c|c|c|c|c|}
\hline \multirow[b]{2}{*}{ Statistic } & \multicolumn{4}{|c|}{ Regression } \\
\hline & {$[1]$} & {$[2]$} & {$[3]$} & {$[4]$} \\
\hline Adjusted $R^{2}$ & 0.157 & 0.182 & 0.202 & 0.188 \\
\hline $\begin{array}{l}F \text { test that all } \\
\text { market coefs equal } 0\end{array}$ & & $\begin{array}{r}1.79 \\
{[.104]}\end{array}$ & & $\begin{array}{r}0.58 \\
{[.746]}\end{array}$ \\
\hline $\begin{array}{l}F \text { test that sum } \\
\text { of market coefs equals } 0\end{array}$ & & $\begin{array}{r}6.29 \\
{[.013]}\end{array}$ & & $\begin{array}{r}2.29 \\
{[.132]}\end{array}$ \\
\hline $\begin{array}{l}F \text { test that all } \\
\text { auto coefs equal } 0\end{array}$ & & & $\begin{array}{r}2.45 \\
{[.028]}\end{array}$ & $\begin{array}{r}1.18 \\
{[.319]}\end{array}$ \\
\hline $\begin{array}{l}F \text { test that sum } \\
\text { of auto coefs equals } 0\end{array}$ & & & $\begin{array}{r}4.64 \\
{[.033]}\end{array}$ & $\begin{array}{r}0.01 \\
{[.904]}\end{array}$ \\
\hline
\end{tabular}

